\title{
6. 慢性副鼻腔炎とアレルギー
}

奥田稔 ・。関根啓一

\section{研究目的}

慢性副䑁腔の成因・経過にアレルギーが大きな役割 をはたしているてとは欧米では広く認められている。 本邦でも近年ての方面での研究が盛んとなり，慢性副 鼻腔炎とアレルギーの関係はしだいに明らかになりつ つある。しかしながら従来アレルギー検查法の不備か らいまだ判然とした結論がでていない，われわれはア レルギー検查法を吟味し，主として吸入性アトピー性 アレルギーの方面から本邦における慢性副鼻腔桨への アレルギーの関与の臨床的意義を解明せんと試みた。

\section{研究方法}

(1)慢性副鼻腔炎患者，(2)鼻アレルギー症状を主訴と して外来を訪れた香者，(3)小児喘息患者，(4)集団検診 した干葉県某羊毛工場女子工員，静岡県某農村民を対 象とし，算鏡検查・アレルギー歴聴取・吸入性アレル ゲンによる皮内反応・誘発反応・鼻汁および血中好酸 球測定・ヒスタミン䙹跕膜反応・組織学的検査・X線 検查 (単純・造影・排泄), 上顎洞内視視鏡検査・自 然孔閉塞度測定を行なつた。

\section{研究 成 績}

(1) アレルギー歴

䁷アでは本人および家族のア歴陽性はそれぞれ $56 \%$ ， 49.5\%でア素因浱厚であるが, 慢性副番热炎（以下慢 副炎）では26\%，25\%で鼎アとはかなりの差が見られ t.

\section{(2) 舅鏡所見}

舅アでは60〜 70\%に粘膜蓬白を認め, 約 40\%が水性

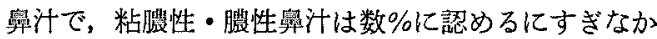
つた．中甲介の变化は整度のものが多く，ポリープは 約 $6 \%$ に見られた。，一方慢副炎では，粘膜嚄白は 24.6 $\%$ ，水性舁汁は少数で大部分粘性〜脹性，中甲介の変 化も強く、ポリープは28.0\%に見られた。

(3) 血中お上び鼻汁中好酸球

急アで血中好酸球增多が約 $50 \%$ ，鼻汁好酸球增多が 約 $80 \%$ 認められた。慢副炎ではそれぞれ15\%，29\%
で皮内，誘発反応ともに陽性例を除いては鼻アとは著 しい差があつた。

(1) 皮内反応

ハウスダスト (HD)，ブタクサ（RW）始め 23 種 の吸入性アレルゲンで皮内反応を行なつた。鼻アでは HD陽性率 60 , RW陽性率 $40 \%$ であつた。 慢副炎では それぞれ $28 \% ， 29 \%$ に陽性，対照群ではそれぞれ14\%， 16\%であつた。すすなわち慢副炎では対照群に比し陽性 率はやや高いが，䁷アに打ける陽性率とはかなりの差 が見られた，他のアレルゲンによる皮内反応陽性率は 慢副炎では $5 \%$ 以下であつた。

(5) 誘発反応

鼻アでは皮内反応陽性例の $56 \%$ に誘発反応陽性であ つた．慢副炎では，皮内反応陽性例の $11.6 \%$ 亿誘発反 応陽泩であつた。

(6) ヒスタミン鼻粘膜反応

鼻アでは陽性率79.4\%，慢副炎では，皮内誘発反応 ともに陽性の例に陽性率 $84.6 \%$ と高率にヒスタミン感 受性が見られた。

(7) X線所見

䙹アではX線陰影（+）のものは約 $50 \%$ にり，陰 影度は比較的軽度のものが多く，洞洗浄液は透明でと きに脴汁を混ずる，粘膜肥厚は $40 \%$ に見られたが，肥 厚度は軽いものが多い，粘膜の茸状変化は $30 \%$ に見ら れ，洞の大きいものに多くみられた，慢副炎ではX線 陰影（+）のものが約70\%にあり，陰影度強いすの多 く，洞洗浄液の多くは粘液〜澧汁を混じていた。約 80 \%に粘膜肥厚が見られ，肥厚度の強いものが多かつた。 革状変化は鼎ア上りやや多く見られ，やはり，洞の大 きいものに多く見られた。

(8) 内視鏡検查

内視鏡検查之同時に自然孔閉塞度測定，洞粘膜を一 部鉗除し，その病理組織検查，造影剤注入し上顎洞造 影，排泄検查を行なつた。

内視鏡所見は Timm の分類にしたがつた，廐アで 
は，変化の少ないものが多く，粘膜の厚さも $3 \mathrm{~mm}$ 以下 のものが多かつた. しかし内視鏡所見も軽度で, 粘膜 も薄く, 自然孔閉塞度 (一)のものでも約半数に排泄 不良例が見られた。これらの組織所見では好酸球浸 潤，杯細胞增生が多くみられた。慢副炎では，内視鏡 所見 $(+)$ 以上のもの多く, 粘膜の厚さ $3 \mathrm{~m}$ 以下では 多くが排泄良好〜中等度で, 自然孔閉塞度 $(-), 5$ 祭 以上では排泄不良なすの多く，自然孔閉塞度 (\#)で あつた。内視鏡之組織所見主に細胞浸潤の比較で, 内 視鏡 $(-)( \pm)$ の多くが組織所見 $(-)( \pm)$, 内視鏡 所見 (+) より（サ）の方に程度の強いものが多くみ られた。好酸球浸潤は舅アでは $45.6 \%$ ，慢副炎では $6.8 \%$ 認められた。

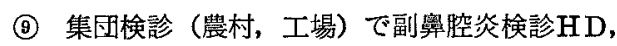
$\mathrm{RW}$ ，羊毛抽夜抗原液皮内反応を行ない，両者の関係
をみたが，特別の関係はみられなかつた。

(10) 小児喘息患児にア検查をすると約 $60 \%$ がアトピ 一性アレルギーであつた. しかしatopic, non-atopic の間で副舆腔炎罹患率に著しい差はみられなかつだ。

(11) 慢副炎手術患者にア検查を行ない術後経過を観 察すると, atop. と感染の混合型の術後経過でア应状 は軽減するが消失せず，他の経過は感染型と変らな い.

(12) 副䁷腔再手術希望者でア検查陽性のものは約 10 \%にあつた.

\section{IV 結吾}

以上より本邦における慢副炎は大部分が感染型であ り，約10\%にアトピー性アレルギーが合併しているて とがわかつた。 